\title{
Review \\ Chronic obstructive pulmonary disease: towards pharmacogenetics
}

\author{
Alice M Wood ${ }^{*}$, See Ling Tan ${ }^{\dagger}$ and Robert A Stockley $\ddagger$
}

\begin{abstract}
Addresses: *University of Birmingham, Birmingham, B15 2TT, UK. †Birmingham Heartlands Hospital, Birmingham, B9 5SS, UK. $\neq$ Lung Investigation Unit, University Hospitals Birmingham, Birmingham, B15 2TH, UK.

Correspondence: Robert A Stockley. Email: r.a.stockley@bham.ac.uk
\end{abstract}

\begin{abstract}
Chronic obstructive pulmonary disease (COPD) is a common problem worldwide, and it is recognized that the term encompasses overlapping sub-phenotypes of disease. The development of a sub-phenotype may be determined in part by an individual's genetics, which in turn may determine response to treatment. A growing understanding of the genetic factors that predispose to COPD and its sub-phenotypes and the pathophysiology of the condition is now leading to the suggestion of individualized therapy based on the patients' clinical phenotype and genotype. Pharmacogenetics is the study of variations in treatment response according to genotype and is perhaps the next direction for genetic research in COPD. Here, we consider how knowledge of the pathophysiology and genetic risk factors for COPD may inform future management strategies for affected individuals.
\end{abstract}

\section{Introduction}

Chronic obstructive pulmonary disease (COPD) is characterized by airflow obstruction, together with an abnormal inflammatory response to noxious particles or gases [1]. COPD is therefore diagnosed by spirometry, in which the ratio between the forced expiratory volume in the first second of expiration (FEV1) and the total volume expired (the forced vital capacity, FVC) is measured; COPD is diagnosed if this ratio is less than 0.7 after the administration of short acting bronchodilators, together with an impaired FEV1 [2]. There are two main classification systems worldwide, issued by national respiratory societies, based on the severity of reduction of FEV1 compared with that predicted by age, gender and height (Table 1). The most widely accepted is the US/European system, which differs from the UK version only in that the most severe level (very severe) is omitted in the UK [3].

Several pathologies can contribute to this impairment of lung function, and it is likely that COPD in its current definition comprises overlapping syndromes. Affected individuals show a range of pathologies, including chronic bronchitis [4], emphysema [5], bronchiectasis or a combination of these. Physiological tests of lung function can also identify impairment of small airway function, which is measured using forced mid-expiratory flow (FEF25-75\%), and impairment of gas transfer, usually reported relative to effective alveolar volume and abbreviated as KCO. The small airways have been of great interest in studies of COPD [6], as changes in their function may be the earliest sign of disease. Impairment of gas transfer usually indicates disease of the lung parenchyma, which in the case of COPD predominantly relates to emphysema. Emphysema can be further subdivided according to its appearance and distribution on high resolution computed tomography (CT) scan. Emphysema in most cases of COPD is typically centrilobular in appearance (in the centre of a given section of lung), and predominantly in the upper regions of each lung. If it is due to a1 antitrypsin deficiency (AATD), the only widely accepted genetic predisposition to emphysema, it is usually panacinar (widespread throughout a given area of the lung) and lower zone dominant [7]. Differences in physiology have been seen according to emphysema zone [8], although this aspect has not been studied in detail for COPD unrelated to AATD. This, together with genetic associations of emphysema zone [9,10], suggest that upper and lower zone emphysema may also be distinct pathologies, which in turn implies that they may respond differently to therapeutic interventions.

COPD is an important epidemiological problem worldwide. The prevalence was estimated to be $7.6 \%$, rising closer to $10 \%$ in adults over 40, in a 2006 systematic review [11]. However, prevalence estimates vary depending on the definition of COPD used and the sub-phenotype studied: the prevalence of chronic bronchitis was estimated at $6.4 \%$

AATD, $\alpha 1$ antitrypsin deficiency; ADRB2, $\beta$ adrenoceptor 2; CHRNA3/5, a nicotinic acetylcholine receptor locus; COPD, chronic obstructive pulmonary disease; CTLA4, cytotoxic T lymphocyte antigen 4; EPHX1, microsomal epoxide hydrolase; FEV1, forced expiratory volume in 1 second; FVC, forced vital capacity; GSTP, glutathione-S-transferase; GWAS, genome-wide association study; HHIP, hedgehog interacting protein; HLA, human leukocyte antigen; IL, interleukin; LABA, long acting $\beta 2$ adrenoceptor agonist; MMP, matrix metalloprotease; PDE4, phosphodiesterase 4; SABA, short acting $\beta 2$ adrenoceptor agonist; SNP, single nucleotide polymorphism; TNFa, tumor necrosis factor alpha. 
Table 1

\begin{tabular}{|c|c|c|}
\hline & British & American and European \\
\hline Mild & $50-80$ & $80-100$ \\
\hline Moderate & $>30$ and $<50$ & $>50$ and $<80$ \\
\hline Severe & $<30$ & $>30$ and $<50$ \\
\hline Very severe & - & $<30$ \\
\hline
\end{tabular}

and of emphysema at $1.8 \%$ [11]. COPD is the registered cause of death in 920 cases per million of the population in the UK [12], and it is estimated that 1.5 million people in the UK have the condition, with up to 1 in 8 hospital admissions related to it [13]. As with many lung diseases, cigarette smoking is an important etiological factor, and is widely accepted to be the main environmental risk factor for developing the disease. Despite this, only about $15 \%$ of smokers develop clinically significant disease [14], suggesting that there are other influences on disease expression. The contribution of smoking has been estimated to be $15 \%$ of the variability in lung function [15], and genetic factors account for a further 40\% [16]. Many genetic predispositions have been reported, increasingly in larger and better characterized populations, with growing confidence about their validity. Here, we briefly review the pathophysiology of COPD, in order to place the current evidence for genetic susceptibility in context, before considering how these features guide current and future management strategies.

\section{The pathophysiology of COPD}

There are three main themes in COPD pathogenesis, which have, to some extent, guided genetic research and are considered in detail below. The first concerns imbalance between proteases that digest elastin and extracellular matrix in the lung and anti-proteases that protect against this process $[17,18]$. Second, disparity between harmful oxidants and protective antioxidants may lead to dominant oxidative stress. Inflammation is the third key concept in COPD pathogenesis.

\section{Protease anti-protease imbalance}

This theory originated from the observation that patients with AATD develop early-onset emphysema [19]. The a1 antitrypsin enzyme is an anti-protease, acting predominantly to block the action of neutrophil elastase, a serine protease released by neutrophils. Two other classes of protease have a role in COPD: cysteine proteases and matrix metalloproteases (MMPs) [20]. Each is inhibited by one or more anti-proteases and may inactivate other antiproteases or activate pro-inflammatory cytokines through proteinase-activated receptors [21]. A key cytokine activated in this way is tumor necrosis factor alpha (TNFa). Proteases clear debris and damaged tissue, but if their action is not effectively controlled, they can produce excessive lung damage.

\section{Oxidative stress}

Cigarette smoke is a major source of oxidants (mainly free radicals and nitric oxide), and reactive oxygen species are also produced by the interaction of smoke with epithelial cells and released by leukocytes, which accumulate in the lungs of smokers [22]. Antioxidant enzymes in the airway include glutathione-S-transferase (GSTP), superoxide dismutase and catalase [23]. Oxidants have direct toxic effects on respiratory epithelium [24], which then enhances pulmonary inflammation by upregulation of genes encoding pro-inflammatory cytokines [24].

\section{Inflammation}

Inflammation can be stimulated by cigarette smoke [22], ozone [25] and particulate matter pollution [26]. Transgenic mouse models illustrate its importance: when interleukin (IL) 13 is overexpressed, mice show induction of MMPs and develop emphysema [27]; by contrast, TNFa knockout mice are relatively protected from emphysema after smoke exposure [28]. In humans, airway infiltration by increasing numbers of inflammatory cells is seen as COPD progresses [6], and airway inflammatory cytokine levels correlate with disease progression [29]. Furthermore, individuals with COPD have higher circulating levels of several inflammatory markers [30], although the relationship between pulmonary and systemic inflammation is not yet clear.

Inflammation drives subsequent proteolytic and oxidant damage in COPD, so understanding the relationships between them is key to understanding its genetic associations and their implications for management. Given the complexity of the inflammatory cascade, combinations of anti-inflammatory, antioxidant and anti-protease drugs might be needed to adequately suppress the disease processes of COPD. With the advent of high-throughput genotyping, it may also become possible to choose treatments on the basis of the importance of each pathogenic process in the individual, something that is at least in part likely to be genetically determined. This concept is referred to as pharmacogenetics - the study of variation in response to medications determined by genotype.

\section{Genetics of COPD}

Airways disease and parenchymal disease are both likely to have a genetic component [31]. Some of the genetic associations that have been replicated in independent patient populations are summarized in Table 2. These focus predominantly on candidate genes suggested by the three pathways outlined above and are in addition to the accepted susceptibility conferred by AATD, which has been reviewed elsewhere [32]. A role for nicotine addiction has also been suggested after an association was observed 
Table 2

\begin{tabular}{|c|c|c|c|c|c|}
\hline Gene* $^{*}$ & Descriptors $^{\dagger}$ & & Function & COPD phenotype & References \\
\hline CHRNA3/5 & $\begin{array}{l}\text { rs8034191 } \\
\text { rs1051730 }\end{array}$ & & & $\begin{array}{l}\text { Airflow obstruction with low FEV1; } \\
\text { FEV1 decline }\end{array}$ & [33] \\
\hline EPHX1 & $\begin{array}{l}\text { rs1051740 } \\
\text { rs2234922 }\end{array}$ & $\begin{array}{l}\text { Tyr213His } \\
\text { His139Arg }\end{array}$ & $\begin{array}{l}\text { Enzyme activity } \downarrow \\
\text { Enzyme activity } \uparrow\end{array}$ & $\begin{array}{l}\text { Emphysema; UZDE; } \\
\text { FEV1 decline }\end{array}$ & {$[9,41,86-90]$} \\
\hline GC & $\begin{array}{l}\text { rs4588 } \\
\text { rs7041 }\end{array}$ & $\begin{array}{l}\text { Thr436Lys } \\
\text { Asp432Glu }\end{array}$ & Conversion to MAF $\downarrow$ & $\begin{array}{l}\text { Emphysema; airflow obstruction } \\
\text { with low FEV1; FEV1 decline }\end{array}$ & [91-93] \\
\hline GSTM1 & Gene deletion & Null & No protein & Emphysema; chronic bronchitis & [94-96] \\
\hline GSTP1 & rs947894 & Ile105Val & Enzyme activity $\uparrow$ & $\begin{array}{l}\text { UZDE; airflow obstruction with low } \\
\text { FEV1; FEV1 decline }\end{array}$ & {$[9,40,95,97-99]$} \\
\hline HHIP & $\begin{array}{l}\text { rs1828591 } \\
\text { rs13118928 }\end{array}$ & & & $\begin{array}{l}\text { Airflow obstruction with low FEV1; } \\
\text { FEV1 decline }\end{array}$ & {$[33,39]$} \\
\hline HMOX1 & $\begin{array}{l}\text { Microsatellite } \\
\text { in promoter }\end{array}$ & $\mathrm{GT}(\mathrm{n})$ & $\begin{array}{l}\text { Gene transcription } \uparrow \\
\text { Enzyme activity } \downarrow\end{array}$ & $\begin{array}{l}\text { Emphysema; airflow obstruction with } \\
\text { low FEV1; FEV1 decline }\end{array}$ & {$[100,101]$} \\
\hline IL1RN & $\begin{array}{l}\text { VNTR tandem } \\
\text { repeat }\end{array}$ & & & COPD & [40] \\
\hline MMP1 & rs1799750 & G-1607GG & Gene transcription $\uparrow$ & UZDE; FEV1 decline & [9] \\
\hline MMP9 & rs3918242 & C-1562T & Gene transcription $\uparrow$ & $\begin{array}{l}\text { UZDE; airflow obstruction with low } \\
\text { FEV1 }\end{array}$ & {$[10,102,103]$} \\
\hline SERPINA3 & $\begin{array}{l}\text { rs4934 } \\
\text { rs17473 } \\
\text { rs1800463 }\end{array}$ & $\begin{array}{l}\text { Ala-15Thr } \\
\text { Pro227Ala } \\
\text { Leu55Pro }\end{array}$ & $\begin{array}{l}\text { Altered protein } \\
\text { Protein level } \downarrow \\
\text { Protein level } \downarrow\end{array}$ & Altered airway resistance & {$[104,105]$} \\
\hline SERPINE2 & Various & $\mathrm{N} / \mathrm{A}$ & $\mathrm{N} / \mathrm{A}$ & Airflow obstruction with low FEV1 & {$[37,47]$} \\
\hline SOD3 & rs1799895 & Arg213Gly & Protein level $\uparrow$ & Airflow obstruction with low FEV1 & [23] \\
\hline SFTPB & $\begin{array}{l}\text { rs1130866 } \\
\text { rs2118177 }\end{array}$ & Thr131lle & Altered protein & $\begin{array}{l}\text { Airflow obstruction with low FEV1; } \\
\text { dyspnoea in emphysema; exacerbation } \\
\text { frequency }\end{array}$ & {$[86,87][106]$} \\
\hline TGFB & $\begin{array}{l}\text { rs1800469 } \\
\text { rs1982073 }\end{array}$ & $\begin{array}{l}\text { C-509T } \\
\text { C613T }\end{array}$ & $\begin{array}{l}\text { Protein level } \uparrow \\
\text { Protein level } \uparrow\end{array}$ & $\begin{array}{l}\text { Airflow obstruction with low FEV1; } \\
\text { dyspnoea in emphysema }\end{array}$ & {$[40,87,107]$} \\
\hline TNFA & rs1800629 & G-308A & Protein level $\uparrow$ & $\begin{array}{l}\text { Emphysema; chronic bronchitis; } \\
\text { airflow obstruction with low FEV1 }\end{array}$ & {$[40,42,108-110]$} \\
\hline
\end{tabular}

${ }^{*}$ Genes with evidence of an effect at genome-wide, meta-analysis or post-Bonferroni-correction level are in bold. ${ }^{\dagger}$ Most modern studies report these associations using the reference SNP number ( $r$...), but older studies often refer to the nucleotide change, whose nomenclature lists the more common allele, followed by the position of the SNP within the gene, and then the least common allele. For example, for TNFA, G-308A refers to a polymorphism at position -308 in the gene, which changes a $\mathrm{G}$ (guanine) residue to an $\mathrm{A}$ (adenine). The negative position indicates that it is in the promoter region. Alternatively, a SNP might be described by the effect it has on its protein product. This follows a similar system to that of nucleotide changes, such that, for example, in SOD3 Arg213Gly indicates a change from an arginine to a glycine residue at position 213 within the protein. Where such descriptors are common in the literature, both the rs number and these are shown. Abbreviations: GC, vitamin D binding protein; HMOX1, heme oxygenase; SFTPB, surfactant protein B; SOD, superoxide dismutase; TGFB, transforming growth factor $\beta$; UZDE, upper zone dominant emphysema.

between polymorphisms in the $\alpha$ nicotinic acetylcholine receptor locus (CHRNA3/5) and COPD in one of the first genome-wide association studies (GWASs) for COPD [33]. Whether this association truly represents altered smoking behavior or is distinct from it is debatable, as there are studies and theoretical reasons to support both arguments [33]. Further GWASs are likely to follow in adequately powered, well characterized cohorts from studies such as ECLIPSE (Evaluation of COPD Longitudinally to Identify Potential Surrogate End points) [34] and COPDGene [35]. GWASs have the potential to discover associations in areas not previously considered important in COPD, implying pathophysiological roles for their protein products, and thus extending our understanding of the condition beyond that of candidate gene studies.

In many cases, replicated associations have been in different sub-groups of patients with COPD, and it is therefore debatable if these are true associations. For this reason it has become the gold standard to report associations in two COPD populations, phenotyped in the same way, in the same publication [36]. Alternatively, confidence in the 
truth of the association might be gained by meta-analysis of the studies of any given polymorphism. Using these stricter standards for genetic association, the genes or regions most likely to be involved are the serine protease gene SERPINE2 [37], the MMP cluster on chromosome 11 [9,38], the CHRNA3/5 locus [33], the hedgehog interacting protein gene HHIP [33,39], the GSTPs [40], IL1RN [40], the microsomal epoxide hydrolase 1 gene (EPHX1) [41] and TNFA [40,42]. Polymorphisms in some of these genes are relevant to known areas of pathogenesis: MMPs relate to protease anti-protease imbalance, the GSTPs and EPHX1 relate to oxidative stress, whereas TNFA and $I L 1 B$ relate to inflammation. The association of SERPINE2 and HHIP deserve a little more consideration, because they imply that hitherto unrecognized proteins contribute to COPD.

SERPINE2 is an inhibitor of trypsin-like serine proteases, related to AAT [43], although its major function is in coagulation and fibrinolysis [44]. It was identified as a potential candidate gene for COPD by integration of an area of linkage on chromosome 2q33 from the Boston early-onset COPD cohort $[45,46]$ with knowledge of gene expression during murine lung development and from human lung microarray datasets [47]. This showed SERPINE2 to be within the area of linkage (chromosome 2q33) and to be highly expressed in the lung, making it a logical candidate gene. Several studies now support a role for this gene in COPD, although the precise location of functional variants has yet to be determined. In the National Emphysema Treatment Trial cohort many SNPs were significantly associated [47] (the most associated being rs6734100 with FEV1/FVC, $P=0.00004$ ), most of which were replicated by the International COPD Genetics Network (ICGN) and in a Norwegian case-control group [37]. Conversely, a large European case-control study did not find any association with COPD [48] and questioned the validity of some of the results reported in the original study given that SNPs in complete linkage disequilibrium in the European cohort had different $P$-values for association from one another in the original study. Overexpression of SERPINE2 is associated with an increased risk of COPD [47], which is not consistent with its protective anti-protease actions. The mechanism of association may be through its role in coagulation because enhanced prothrombotic markers are associated with decline of FEV1 in COPD [49], although the role of such pathways in COPD pathogenesis has not been widely investigated. Alternatively, SERPINE2mediated inhibition of plasminogen activator urokinase may be important, as this kinase is involved in activation of TGF $\beta$ and MMPs and is overexpressed in COPD [50]. These are certainly promising avenues for future pharmacological interventions, to which SERPINE2 genotype may be relevant, but further research is needed in this area.

Two SNPs within the HHIP gene (rs1851851 and rs13118928, both $P<2 \times 10^{-7}$ ) showed a protective effect against COPD with a mean odds ratio of 0.72 [33], findings that are supported by a GWAS examining lung function in the general population [39]. Their functional significance is not yet clear: HHIP encodes a signaling molecule (HIP1) that is present in most mammalian tissues [51] and interacts with hedgehog proteins to control morphogenesis [52]. Its precise role in the lung is not yet known. However, its association with disease implies a role in COPD pathogenesis, but whether this would be amenable to pharmacological intervention or represents a developmental abnormality less amenable to change is not yet known.

\section{Management of COPD}

Therapy for COPD is mainly directed at airflow obstruction and inflammation, with additional treatment for exacerbations, which may be infective or non-infective. Thus, shortand long-acting bronchodilators, acting via $\beta$ adrenoceptors ( $\beta_{2}$ agonists) and anticholinergic pathways, are recommended to be used in a stepwise manner, with the addition of inhaled steroids later in the disease. Current British Thoracic Society guidelines suggest that inhaled steroids should be combined with a long acting $\beta 2$ agonist (LABA) and prescribed to patients when FEV1 is below $60 \%$ of the predicted normal value, and when the patient is experiencing regular exacerbations [3]. Many of the newer treatments for COPD have been directed at individual components of inflammation, given its importance in pathogenesis. However, most, such as anti-TNFa therapies, have been disappointing [53]. Treatment response differences between sub-phenotypes of COPD, which coexist in some study populations, could be a key factor. Some of the newer treatment strategies and their effects in clinical trials are shown in Table 3. Non-pharmacological interventions, such as pulmonary rehabilitation, which aims to improve patient fitness, are also effective [54], although it is possible that this too is influenced by genetics given the recent report of association of muscle wasting in COPD with the vitamin D receptor gene [55].

\section{How can genetics contribute to management of COPD in the future?}

The concept of pharmacogenetics and individually tailored therapy is now entering respiratory medicine, and reviews of the topic have recently been published with regard to asthma [56] and lung cancer [57]. Specific pharmacogenetic studies of COPD are currently missing from the medical literature but those for asthma are growing in number $[58,59]$. This suggests that similar work may follow for COPD, given that elements of treatment strategy, including bronchodilation, are the same for the two conditions. We can thus only speculate on the directions that pharmacogenetics of COPD may take, on the basis of current knowledge of the variation in treatment response to the classes of drug now used for COPD and that are entering the market, as described below. The future assessment of COPD and choice of management strategies 
Table 3

\begin{tabular}{|c|c|c|c|c|c|}
\hline Treatment & Mechanism & Clinical effects & $\begin{array}{l}\text { Genes } \\
\text { associated with } \\
\text { response to } \\
\text { therapy* }^{*}\end{array}$ & $\begin{array}{c}\text { Genes } \\
\text { associated } \\
\text { with } \\
\text { COPD }^{\dagger}\end{array}$ & References $\ddagger$ \\
\hline Cilomilast & PDE4 inhibitor & $\begin{array}{l}\text { Improvement in FEV1 and quality of life; } \\
\text { reduced FEV1 decline; fewer exacerbations }\end{array}$ & - & PDE4 & {$[72,73,75]$} \\
\hline Roflumilast & PDE4 inhibitor & Improvement in FEV1 & - & PDE4 & {$[74]$} \\
\hline BAY $\times 1005$ & LTB4 synthesis inhibitor & Reduced bronchial inflammation & - & - & [111] \\
\hline ABX-IL8 & $\begin{array}{l}\text { Monoclonal antibody } \\
\text { specific to IL8 }\end{array}$ & $\begin{array}{l}\text { Improvement in dyspnoea and FEV1 early } \\
\text { in treatment, but no sustained improvement } \\
\text { in lung function by the end of the trial }\end{array}$ & - & - & [112] \\
\hline $\mathrm{N}$-acetylcysteine & Antioxidant & $\begin{array}{l}\text { No improvement in lung function or } \\
\text { exacerbation frequency }\end{array}$ & - & $\begin{array}{l}\text { GSTP1, GSTM1, } \\
\text { EPHX1, SOD3 } \\
\text { and } H M O X 1\end{array}$ & [113] \\
\hline Infliximab & Anti-TNFa & $\begin{array}{l}\text { No benefit except in cachectic participants, } \\
\text { whose } 6 \mathrm{MWT} \text { distance and frequency of } \\
\text { hospital admissions improved }\end{array}$ & TNFA & TNFA & {$[53,79]$} \\
\hline Marimastat & MMP inhibitor & $\begin{array}{l}\text { Tested in asthma; reduced airway } \\
\text { hyper-responsiveness }\end{array}$ & - & $\begin{array}{l}\text { MMP1 and } \\
M M P 9\end{array}$ & [114] \\
\hline $\begin{array}{l}\text { All-trans-retinoic } \\
\text { acid }\end{array}$ & $\begin{array}{l}\text { Repairs elastase/smoke } \\
\text { induced lung damage }\end{array}$ & $\begin{array}{l}\text { Clinical trials in progress; pilot studies } \\
\text { confirm safety }\end{array}$ & - & - & [115] \\
\hline Montelukast & $\begin{array}{l}\text { Leukotriene receptor } \\
\text { antagonist }\end{array}$ & $\begin{array}{l}\text { Improved FEV1 and quality of life; } \\
\text { observational study suggested reduced } \\
\text { hospital admissions and medication usage }\end{array}$ & LTC4 synthase & - & {$[59,116,117]$} \\
\hline
\end{tabular}

${ }^{*}$ Refers to all studies of the drug class, which may have been carried out on other diseases. 'Refers to genes relevant to the pathways on which each listed drug acts. ‡Refers to publications reporting clinical drug trials, studies of pharmacogenetics, and those genetic association studies not listed in Table 2. Further details can be found in the text. Abbreviations: LTB4, leukotriene B4; 6MWT, 6 minute walk test.

might use both phenotyping and genotyping to guide choice of medication in each patient, perhaps using an algorithm such as that shown in Figure 1.

\section{Established treatments for COPD}

Short acting $\beta_{2}$ agonists (SABAs) and LABAs are both important for treatment for COPD and asthma, because of their bronchodilator effects. However, some controversy over their use, at least for asthma, has occurred because LABAs have been associated with increased mortality [6o]. Variation in response to both SABAs [61] and LABAs [62] has been observed with polymorphisms in the $\beta 2$ adrenoceptor gene (ADRB2), one of which has also been associated with COPD [63]. The degree of reversibility of airflow obstruction shown by patients with COPD also varies considerably [64], although this relationship with $A D B R 2$ genotype has not been studied. LABAs also have anti-inflammatory properties [65] that might prompt their continued use in COPD regardless of $A D B R 2$ genotype, but the possibility remains that there is a sub-group within COPD patients who may benefit more from such therapy than others.

Oral steroids are an established treatment for exacerbations of COPD and are used widely to treat autoimmunity because of their immunosuppressive effects. There has been a suggestion of a role for autoimmunity in COPD $[66,67]$, and the association of polymorphisms in CTLA4 [68], and possibly of human leukocyte antigen (HLA) type [69], with the condition suggests that there may be patients for whom this aspect of pathophysiology is important. Variation in both CTLA4 [70] and the HLA region [71] is associated with other autoimmune diseases that typically respond to immunosuppression, suggesting that this might be a management strategy worth pursuing, in the stable state, for some individuals with COPD. Usually such treatments, in the form of oral steroids, are reserved for exacerbations of the disease, but if there is an autoimmune component, oral steroids and other immunosuppressants might be effective at other times as well.

\section{New treatments for COPD}

Phosphodiesterase 4 (PDE4) inhibitors are a promising COPD treatment [72-74], although gastrointestinal side effects necessitated cessation of therapy in $9 \%$ of subjects on the PDE4 inhibitor cilomilast [72]. PDE4 polymorphisms have been associated with COPD [75], suggesting that there may be groups of patients for whom these pathways are particularly important in disease or who may respond differently to PDE4 inhibition. Similarly, MMP 


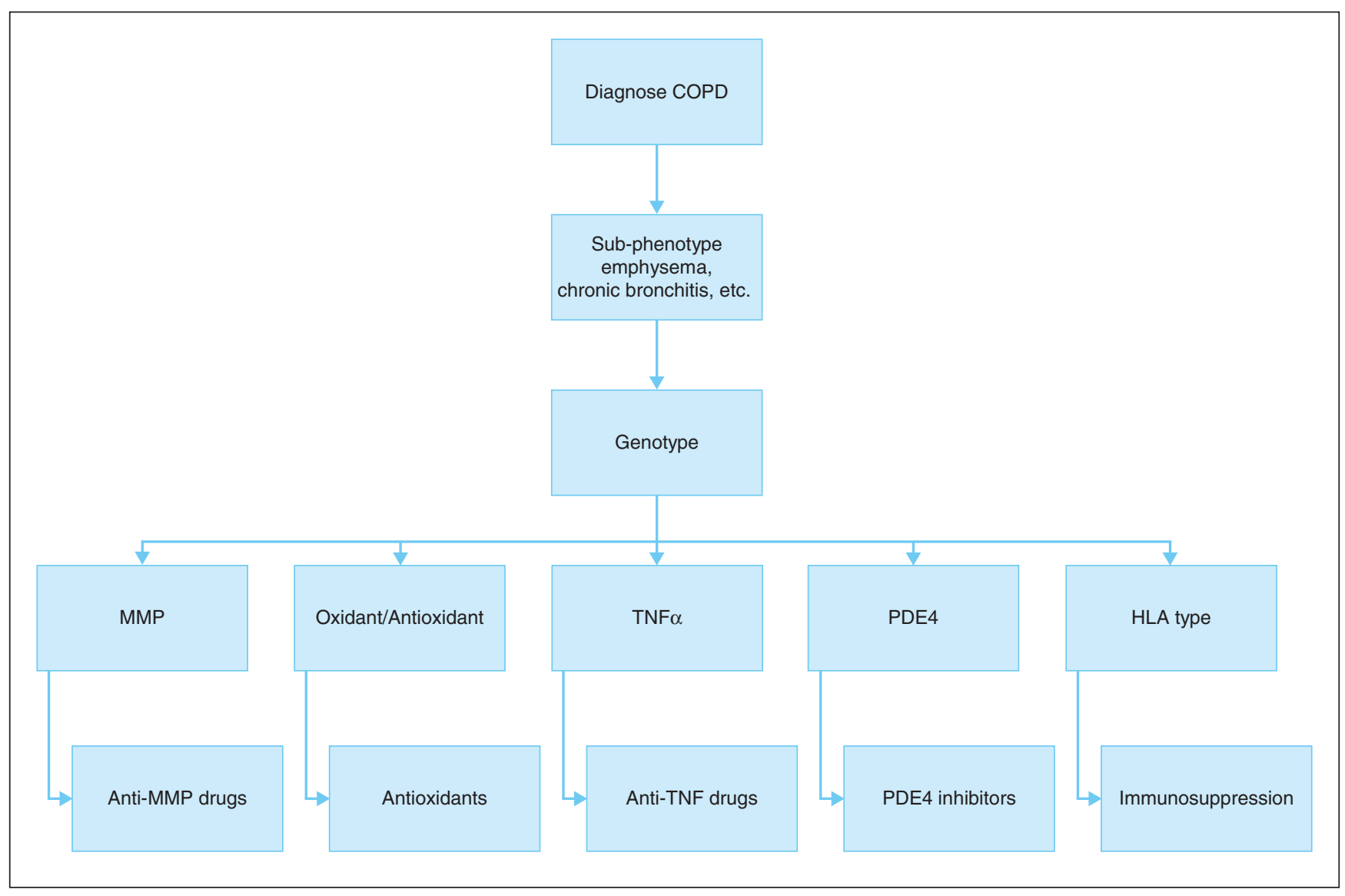

Figure 1

A possible COPD treatment algorithm based on pharmacogenetics. The chart shows a hypothetical system of using pharmacogenetics in COPD. After receiving a diagnosis of COPD, patients would undergo further tests to identify specific clinical features known to be influenced by genetics. Genotyping for the important polymorphisms would then be carried out to identify pathophysiologically important pathways, and therapy would be directed at those most active in the individual. Specific monitoring of response using target protein levels or clinical phenotype would then be carried out. This treatment algorithm might be used alongside established treatments, such as bronchodilators, or be used to aid rational use of expensive treatments.

inhibitors have been limited in their clinical use because of side effects [76], but they may be most appropriately used in individuals for whom MMP-driven lung damage is the most important aspect of their COPD. Genetic variation may underlie increased MMP activity, particularly in upper-zone-dominant emphysema [9,10], such that genotyping or specific phenotyping could identify patients most likely to benefit from treatment with this class of drug in COPD clinical trials.

The results of the major controlled trial of anti-TNFa therapy in COPD, while not beneficial overall, gave the first hint that there might be subgroups within COPD that respond differently because the cachectic patients (those who were losing body mass, particularly fat free mass, regardless of food intake) showed better exercise capacity on the drug [53]. This is consistent with the putative role of TNFa in systemic disease [77]. Infliximab is used to treat a variety of other inflammatory conditions, such as Crohn's disease and rheumatoid arthritis, both of which are associated with variation in genes related to $T N F \alpha$ [78], and the response to infliximab relates to $T N F \alpha$ genotype [79]. If there are sub-phenotypes of COPD that are clearly associated with polymorphisms in $T N F \alpha$, this would provide a rationale for more targeted testing of anti-TNFa treatments.

Reductions in COPD mortality have been observed with statins [80], another class of drug whose efficacy may be determined in part by genetic background [81]. This drug class may be worthy of a more focused study in patients with both COPD and cardiovascular disease, a co-morbidity likely to result from shared inflammatory mechanisms [82]. Indeed, co-morbidities may result from shared genetic susceptibility, suggesting that therapies targeting these pathways have potential to treat several conditions 
simultaneously. For example, both diabetes and low FEV1 show association with genes related to IL6 pathways $[83,84]$, and arterial disease and emphysema are both associated with variation in the $M M P 9$ promoter $[10,85]$.

Leukotriene antagonists are used widely in asthma, but not yet in COPD, although there is some evidence of benefit (Table 3). This class of drug has been studied recently regarding its pharmacokinetics in asthmatics, and variations in response linked to polymorphism of the leukotriene $\mathrm{C}_{4}$ synthase gene [59]. Although this gene has not been studied in COPD, this study [59] offers further evidence that clinical response to general classes of drug likely to be of benefit in airways disease may vary according to genetic background.

\section{Conclusions}

Growing understanding of the genetics and mechanisms underlying COPD and the resultant sub-phenotypes of COPD supports a hypothesis that there may be identifiable groups of patients who will respond differently to treatments. This is because their underlying genotype has the potential to determine not only the specific pathological processes underlying a clinical phenotype of disease, which may dictate treatment response, but also influences drug metabolism and thus efficacy. This makes the study of pharmacogenetics an exciting prospect for COPD in the years to come.

\section{Competing interests}

AMW and SLT declare they have no competing interests. RAS has received non-commercial grant funding from Talecris Biotherapeutics, who have not contributed to or reviewed this article.

\section{Authors' contributions}

AMW and SLT drafted the article. RAS reviewed and approved it for submission.

\section{References}

1. GOLD - the Global initiative for Obstructive Lung Disease [http://www.goldcopd.org/]

2. Pellegrino R, Viegi G, Brusasco V, Crapo RO, Burgos F, Casaburi R, Coates A, van der Grinten CP, Gustafsson P, Hankinson J, Jensen R, Johnson DC, Maclntyre N, McKay R, Miller MR, Navajas D, Pedersen OF, Wanger J: Interpretative strategies for lung function tests. Eur Respir J 2005, 26:948968.

3. Management of chronic obstructive pulmonary disease in adults in primary and secondary care [http://www.nice.org. uk/nicemedia/pdf/CG012 niceguideline.pdf]

4. American Thoracic Society: Chronic bronchitis, asthma and pulmonary emphysema: a statement by the committee on diagnostic standards for non-tuberculous respiratory diseases. Am Rev Resp Dis 1962, 85:762-768.

5. Snider G, Kleineman J, Thurlbeck W, Bengali Z: The definition of emphysema: a report of the National Heart, Lung and Blood Institute, Division of Lung Diseases Workshop. Am Rev Resp Dis 1985, 132:182-185.

6. Hogg JC, Chu F, Utokaparch S, Woods R, Elliott WM, Buzatu L, Cherniack RM, Rogers RM, Sciurba FC, Coxson HO, Pare
PD: The nature of small-airway obstruction in chronic obstructive pulmonary disease. N Engl J Med 2004, 350: 2645-2653.

7. Needham M, Stockley RA: Alpha 1-antitrypsin deficiency. 3: Clinical manifestations and natural history. Thorax 2004, 59:441-445.

8. Parr DG, Stoel BC, Stolk J, Stockley RA: Pattern of emphysema distribution in alpha1-antitrypsin deficiency influences lung function impairment. Am J Respir Crit Care Med 2004, 170:1172-1178.

9. Demeo DL, Hersh CP, Hoffman EA, Litonjua AA, Lazarus $R$, Sparrow D, Benditt JO, Criner G, Make B, Martinez FJ, Scanlon PD, Sciurba FC, Utz JP, Reilly JJ, Silverman EK: Genetic determinants of emphysema distribution in the national emphysema treatment trial. Am J Respir Crit Care Med 2007, 176:42-48.

10. Ito I, Nagai S, Handa T, Muro S, Hirai T, Tsukino M, Mishima M: Matrix metalloproteinase-9 promoter polymorphism associated with upper lung dominant emphysema. Am J Respir Crit Care Med 2005, 172:1378-1382.

11. Halbert RJ, Natoli JL, Gano A, Badamgarav E, Buist AS, Mannino DM: Global burden of COPD: systematic review and meta-analysis. Eur Respir J 2006, 28:523-532.

12. Office for National Statistics: Mortality Statistics: Review of the Registrar General on Deaths by Cause, Sex and Age in England and Wales, 2005. London: Office for National Statistics; 2006.

13. Chronic obstructive pulmonary disease. National clinical guideline on management of chronic obstructive pulmonary disease in adults in primary and secondary care. Thorax 2004, 59(Suppl 1):1-232.

14. American Thoracic Society: Cigarette smoking and health. Am J Respir Crit Care Med 1996, 153:861-865.

15. Burrows B, Knudson R, Cline M, Lebowitz M: Quantitative relationship between cigarette smoking and ventilatory function. Am Rev Resp Dis 1977, 115:195-205.

16. Coultas DB, Hanis CL, Howard CA, Skipper BJ, Samet JM: Heritability of ventilatory function in smoking and nonsmoking New Mexico Hispanics. Am Rev Respir Dis 1991, 144:770-775.

17. Stockley RA: Neutrophils and protease/antiprotease imbalance. Am J Respir Crit Care Med 1999, 160:S49-S52.

18. Shapiro SD, Senior RM: Matrix metalloproteinases. Matrix degradation and more. Am J Respir Cell Mol Biol 1999, 20: 1100-1102.

19. Eriksson S: Studies in alpha 1 antitrypsin deficiency. Acta Med Scand Suppl 1965, 432:1-85.

20. Barnes PJ, Shapiro SD, Pauwels RA: Chronic obstructive pulmonary disease: molecular and cellular mechanisms. Eur Respir J 2003, 22:672-688.

21. Dery O, Corvera CU, Steinhoff M, Bunnett NW: Proteinaseactivated receptors: novel mechanisms of signaling by serine proteases. Am J Physiol 1998, 274:C1429-C1452.

22. Hunninghake GW, Crystal RG: Cigarette smoking and lung destruction. Accumulation of neutrophils in the lungs of cigarette smokers. Am Rev Respir Dis 1983, 128:833-838.

23. Young RP, Hopkins R, Black PN, Eddy C, Wu L, Gamble GD, Mills GD, Garrett JE, Eaton TE, Rees MI: Functional variants of antioxidant genes in smokers with COPD and in those with normal lung function. Thorax 2006, 61:394-399.

24. MacNee W: Oxidants/antioxidants and COPD. Chest 2000 117:303S-317S

25. Devlin RB, McDonnell WF, Becker S, Madden MC, McGee MP, Perez R, Hatch G, House DE, Koren HS: Time-dependent changes of inflammatory mediators in the lungs of humans exposed to $0.4 \mathrm{ppm}$ ozone for $2 \mathrm{hr}$ : a comparison of mediators found in bronchoalveolar lavage fluid 1 and $18 \mathrm{hr}$ after exposure. Toxicol Appl Pharmacol 1996, 138:176-185.

26. Li XY, Gilmour PS, Donaldson K, MacNee W: Free radical activity and pro-inflammatory effects of particulate air pollution (PM10) in vivo and in vitro. Thorax 1996, 51:12161222. 
27. Zheng T, Zhu Z, Wang Z, Homer RJ, Ma B, Riese RJ Jr, Chapman HA Jr, Shapiro SD, Elias JA: Inducible targeting of IL-13 to the adult lung causes matrix metalloproteinaseand cathepsin-dependent emphysema. J Clin Invest 2000, 106:1081-1093.

28. Churg A, Wang RD, Tai H, Wang X, Xie C, Wright JL: Tumor necrosis factor-alpha drives $70 \%$ of cigarette smokeinduced emphysema in the mouse. Am J Respir Crit Care Med 2004, 170:492-498.

29. Parr DG, White AJ, Bayley DL, Guest PJ, Stockley RA: Inflammation in sputum relates to progression of disease in subjects with COPD: a prospective descriptive study. Respir Res 2006, 7:136.

30. Gan WQ, Man SF, Senthilselvan A, Sin DD: Association between chronic obstructive pulmonary disease and systemic inflammation: a systematic review and a meta-analysis. Thorax 2004, 59:574-580.

31. Patel BD, Coxson HO, Pillai SG, Agusti AG, Calverley PM, Donner CF, Make BJ, Muller NL, Rennard SI, Vestbo J, Wouters EF, Hiorns MP, Nakano Y, Camp PG, Nasute Fauerbach PV, Screaton NJ, Campbell EJ, Anderson WH, Pare PD, Levy RD, Lake SL, Silverman EK, Lomas DA: Airway wall thickening and emphysema show independent familial aggregation in chronic obstructive pulmonary disease. $\mathrm{Am}$ J Respir Crit Care Med 2008, 178:500-505.

32. Wood AM, Stockley RA: Alpha one antitrypsin deficiency: from gene to treatment. Respiration 2007, 74:481-492.

33. Pillai SG, Ge D, Zhu G, Kong X, Shianna KV, Need AC, Feng S, Hersh CP, Bakke P, Gulsvik A, Ruppert A, Lodrup Carlsen KC, Roses A, Anderson W, Rennard SI, Lomas DA, Silverman EK, Goldstein DB: A genome-wide association study in chronic obstructive pulmonary disease (COPD): identification of two major susceptibility loci. PLOS Genet 2009, 5: e1000421.

34. Vestbo J, Anderson W, Coxson HO, Crim C, Dawber F, Edwards L, Hagan G, Knobil K, Lomas DA, MacNee W, Silverman EK, Tal-Singer R: Evaluation of COPD longitudinally to identify predictive surrogate end-points (ECLIPSE). Eur Respir J 2008, 31:869-873.

35. COPD Genetic Epidemiology [http://www.copdgene.org]

36. Colhoun HM, McKeigue PM, Davey Smith G: Problems of reporting genetic associations with complex outcomes. Lancet 2003, 361:865-872.

37. Zhu G, Warren L, Aponte J, Gulsvik A, Bakke P, Anderson WH, Lomas DA, Silverman EK, Pillai SG: The SERPINE2 gene is associated with chronic obstructive pulmonary disease in two large populations. Am J Respir Crit Care Med 2007, 176: 167-173.

38. Kong X, Coxson HO, Lomas DA, Silverman EK, Pillai SG: Genome-wide association study (GWA) of high resolution CT defined emphysema phenotypes in two independent COPD populations [abstract]. Am J Respir Crit Care Med 2009, 179:A2444.

39. Wilk JB, Chen TH, Gottlieb DJ, Walter RE, Nagle MW, Brandler BJ, Myers RH, Borecki IB, Silverman EK, Weiss ST, O'Connor GT: A genome-wide association study of pulmonary function measures in the Framingham Heart Study. PLoS Genet 2009, 5:e1000429.

40. Smolonska J, Wijmenga C, Postma DS, Boezen HM: Metaanalyses on suspected COPD genes - a summary of 20 years' research. Am J Respir Crit Care Med 2009, 180:618631.

41. Hu G, Shi Z, Hu J, Zou G, Peng G, Ran P: Association between polymorphisms of microsomal epoxide hydrolase and COPD: results from meta-analyses. Respirology 2008, 13:837-850.

42. Gingo MR, Silveira LJ, Miller YE, Friedlander AL, Cosgrove GP, Chan ED, Maier LA, Bowler RP: Tumour necrosis factor gene polymorphisms are associated with COPD. Eur Respir J 2008, 31:1005-1012.

43. Scott RW, Bergman BL, Bajpai A, Hersh RT, Rodriguez $H$, Jones BN, Barreda C, Watts S, Baker JB: Protease nexin. Properties and a modified purification procedure. $\mathrm{J}$ Biol Chem 1985, 260:7029-7034.
44. Baker JB, Low DA, Simmer RL, Cunningham DD: Proteasenexin: a cellular component that links thrombin and plasminogen activator and mediates their binding to cells. Cell 1980, 21:37-45

45. Silverman EK, Mosley JD, Palmer LJ, Barth M, Senter JM Brown A, Drazen JM, Kwiatkowski DJ, Chapman HA, Campbell EJ, Province MA, Rao DC, Reilly JJ, Ginns LC, Speizer FE, Weiss ST: Genome-wide linkage analysis of severe, earlyonset chronic obstructive pulmonary disease: airflow obstruction and chronic bronchitis phenotypes. Hum Mol Genet 2002, 11:623-632.

46. Silverman EK, Palmer LJ, Mosley JD, Barth M, Senter JM, Brown A, Drazen JM, Kwiatkowski DJ, Chapman HA, Campbell EJ, Province MA, Rao DC, Reilly JJ, Ginns LC, Speizer FE, Weiss ST: Genomewide linkage analysis of quantitative spirometric phenotypes in severe early-onset chronic obstructive pulmonary disease. Am J Hum Genet 2002, 70 : 1229-1239.

47. Demeo DL, Mariani TJ, Lange C, Srisuma S, Litonjua AA Celedon JC, Lake SL, Reilly JJ, Chapman HA, Mecham BH, Haley KJ, Sylvia JS, Sparrow D, Spira AE, Beane J, Pinto-Plata V, Speizer FE, Shapiro SD, Weiss ST, Silverman EK: The SERPINE2 gene is associated with chronic obstructive pulmonary disease. Am J Hum Genet 2006, 78:253-264.

48. Chappell S, Daly L, Morgan K, Baranes TG, Roca J, Rabinovich R, Millar A, Donnelly SC, Keatings $V$, MacNee W, Stolk J, Hiemstra PS, Miniati M, Monti S, O'Connor CM, Kalsheker N: The SERPINE2 gene and chronic obstructive pulmonary disease. Am J Hum Genet 2006, 79:184-186; author reply 186-187.

49. Ashitani J, Mukae $\mathrm{H}$, Arimura $\mathrm{Y}$, Matsukura S: Elevated plasma procoagulant and fibrinolytic markers in patients with chronic obstructive pulmonary disease. Intern Med 2002, 41:181-185.

50. Wang IM, Stepaniants S, Boie Y, Mortimer JR, Kennedy B, Elliott M, Hayashi S, Loy L, Coulter S, Cervino S, Harris J, Thornton M, Raubertas R, Roberts C, Hogg JC, Crackower M, O'Neill G, Pare PD: Gene expression profiling in patients with chronic obstructive pulmonary disease and lung cancer. Am J Respir Crit Care Med 2008, 177:402-411.

51. Bak M, Hansen $C$, Friis Henriksen $K$, Tommerup $N$ : The human hedgehog-interacting protein gene: structure and chromosome mapping to 4q31.21-->q31.3. Cytogenet Cell Genet 2001, 92:300-303.

52. Gao B, Hu J, Stricker S, Cheung M, Ma G, Law KF, Witte F, Briscoe J, Mundlos S, He L, Cheah KS, Chan D: A mutation in Ihh that causes digit abnormalities alters its signalling capacity and range. Nature 2009, 458:1196-1200.

53. Rennard SI, Fogarty C, Kelsen S, Long W, Ramsdell J, Allison J, Mahler D, Saadeh C, Siler T, Snell P, Korenblat P, Smith W, Kaye M, Mandel M, Andrews C, Prabhu R, Donohue JF, Watt $\mathrm{R}$, Lo KH, Schlenker-Herceg R, Barnathan ES, Murray J: The safety and efficacy of infliximab in moderate to severe chronic obstructive pulmonary disease. Am J Respir Crit Care Med 2007, 175:926-934.

54. Celli BR, MacNee W: Standards for the diagnosis and treatment of patients with COPD: a summary of the ATS/ERS position paper. Eur Respir J 2004, 23:932-946.

55. Hopkinson NS, Li KW, Kehoe A, Humphries SE, Roughton M, Moxham J, Montgomery H, Polkey Ml: Vitamin D receptor genotypes influence quadriceps strength in chronic obstructive pulmonary disease. Am J Clin Nutr 2008, 87: 385-390.

56. Lima JJ, Blake KV, Tantisira KG, Weiss ST: Pharmacogenetics of asthma. Curr Opin Pulm Med 2009, 15:57-62.

57. Perez-Soler R: Individualized therapy in non-small-cell lung cancer: future versus current clinical practice. Oncogene 2009, 28(Suppl 1):S38-S45.

58. Koster ES, Raaijmakers JA, Koppelman GH, Postma DS, van der Ent CK, Koenderman L, Bracke M, Maitland-van der Zee $\mathrm{AH}$ : Pharmacogenetics of anti-inflammatory treatment in children with asthma: rationale and design of the PACMAN cohort. Pharmacogenomics 2009, 10:1351-1361. 
59. Asano K, Nakade S, Shiomi T, Nakajima T, Suzuki Y, Fukunaga $\mathrm{K}$, Oguma T, Sayama K, Fujita H, Tanigawara Y, Ishizaka A: Impact of pharmacokinetics and pharmacogenetics on the efficacy of pranlukast in Japanese asthmatics. Respirology 2009, 14:822-827.

60. Salpeter SR, Buckley NS, Ormiston TM, Salpeter EE: Metaanalysis: effect of long-acting beta-agonists on severe asthma exacerbations and asthma-related deaths. Ann Intern Med 2006, 144:904-912.

61. Israel E, Drazen JM, Liggett SB, Boushey HA, Cherniack RM, Chinchilli VM, Cooper DM, Fahy JV, Fish JE, Ford JG, Kraft M, Kunselman S, Lazarus SC, Lemanske RF, Martin RJ, McLean DE, Peters SP, Silverman EK, Sorkness CA, Szefler SJ, Weiss ST, Yandava CN: The effect of polymorphisms of the beta(2)-adrenergic receptor on the response to regular use of albuterol in asthma. Am J Respir Crit Care Med 2000, 162: 75-80.

62. Wechsler ME, Lehman E, Lazarus SC, Lemanske RF Jr, Boushey HA, Deykin A, Fahy JV, Sorkness CA, Chinchilli VM, Craig TJ, DiMango E, Kraft M, Leone F, Martin RJ, Peters SP, Szefler SJ, Liu W, Israel E: Beta-Adrenergic receptor polymorphisms and response to salmeterol. Am J Respir Crit Care Med 2006, 173:519-526.

63. Hegab AE, Sakamoto T, Saitoh W, Massoud HH, Massoud HM, Hassanein KM, Sekizawa K: Polymorphisms of IL4, IL13, and ADRB2 genes in COPD. Chest 2004, 126:1832-1839.

64. Calverley PM, Burge PS, Spencer S, Anderson JA, Jones PW: Bronchodilator reversibility testing in chronic obstructive pulmonary disease. Thorax 2003, 58:659-664.

65. Jeffery PK, Venge P, Gizycki MJ, Egerod I, Dahl R, Faurschou $P$ : Effects of salmeterol on mucosal inflammation in asthma: a placebo-controlled study. Eur Respir J 2002, 20: 1378-1385.

66. Lee SH, Goswami S, Grudo A, Song LZ, Bandi V, GoodnightWhite S, Green L, Hacken-Bitar J, Huh J, Bakaeen F, Coxson $\mathrm{HO}$, Cogswell S, Storness-Bliss C, Corry DB, Kheradmand F: Antielastin autoimmunity in tobacco smoking-induced emphysema. Nat Med 2007, 13:567-569.

67. Feghali-Bostwick CA, Gadgil AS, Otterbein LE, Pilewski JM, Stoner MW, Csizmadia E, Zhang Y, Sciurba FC, Duncan SR: Autoantibodies in patients with chronic obstructive pulmonary disease. Am J Respir Crit Care Med 2008, 177:156-163.

68. Zhu G, Agusti A, Gulsvik A, Bakke P, Coxson H, Lomas DA, Silverman EK, Pillai SG: CTLA4 gene polymorphisms are associated with chronic bronchitis. Eur Respir J 2009, 34:598-604.

69. Wood AM, Ahmad A, Stockley RA: Anti-elastin autoimmunity in emphysema related to alpha-1-antitrypsin deficiency. Am J Respir Crit Care Med 2009, 179:A1009.

70. Ueda H, Howson JM, Esposito L, Heward J, Snook H, Chamberlain G, Rainbow DB, Hunter KM, Smith AN, Di Genova G, Herr MH, Dahlman I, Payne F, Smyth D, Lowe C, Twells RC, Howlett S, Healy B, Nutland S, Rance HE, Everett V, Smink LJ, Lam AC, Cordell HJ, Walker NM, Bordin C, Hulme J, Motzo C, Cucca F, Hess JF, et al.: Association of the T-cell regulatory gene CTLA4 with susceptibility to autoimmune disease. Nature 2003, 423:506-511

71. Simmonds MJ, Gough SC: The HLA region and autoimmune disease: associations and mechanisms of action. Curr Genomics 2007, 8:453-465.

72. Rennard SI, Schachter N, Strek M, Rickard K, Amit O: Cilomilast for COPD: results of a 6-month, placebo-controlled study of a potent, selective inhibitor of phosphodiesterase 4. Chest 2006, 129:56-66.

73. Compton $\mathrm{CH}$, Gubb J, Nieman R, Edelson J, Amit O, Bakst A, Ayres JG, Creemers JP, Schultze-Werninghaus G, Brambilla C, Barnes NC: Cilomilast, a selective phosphodiesterase-4 inhibitor for treatment of patients with chronic obstructive pulmonary disease: a randomised, dose-ranging study. Lancet 2001, 358:265-270.

74. Rabe KF, Bateman ED, O'Donnell D, Witte S, Bredenbroker D, Bethke TD: Roflumilast--an oral anti-inflammatory treatment for chronic obstructive pulmonary disease: a randomised controlled trial. Lancet 2005, 366:563-571.
75. Homma S, Sakamoto T, Hegab AE Saitoh W, Nomura A, Ishii Y, Morishima Y, lizuka T, Kiwamoto T, Matsuno Y, Massoud HH, Massoud HM, Hassanein KM, Sekizawa K: Association of phosphodiesterase 4D gene polymorphisms with chronic obstructive pulmonary disease: relationship to interleukin 13 gene polymorphism. Int J Mol Med 2006, 18:933-939.

76. Sparano JA, Bernardo P, Stephenson P, Gradishar WJ, Ingle JN, Zucker S, Davidson NE: Randomized phase III trial of marimastat versus placebo in patients with metastatic breast cancer who have responding or stable disease after first-line chemotherapy: Eastern Cooperative Oncology Group trial E2196. J Clin Oncol 2004, 22:4683-4690.

77. Sevenoaks MJ, Stockley RA: Chronic obstructive pulmonary disease, inflammation and co-morbidity--a common inflammatory phenotype? Respir Res 2006, 7:70.

78. Wellcome Trust Case Control Consortium: Genome-wide association study of 14,000 cases of seven common diseases and 3,000 shared controls. Nature 2007, 447:661-678.

79. Seitz M, Wirthmuller U, Moller B, Villiger PM: The $\mathbf{- 3 0 8}$ tumour necrosis factor-alpha gene polymorphism predicts therapeutic response to TNFalpha-blockers in rheumatoid arthritis and spondyloarthritis patients. Rheumatology (Oxford) 2007, 46:93-96.

80. Soyseth V, Brekke PH, Smith P, Omland T: Statin use is associated with reduced mortality in COPD. Eur Respir J 2007, 29:279-283

81. Chasman DI, Posada D, Subrahmanyan L, Cook NR, Stanton VP Jr, Ridker PM: Pharmacogenetic study of statin therapy and cholesterol reduction. JAMA 2004, 291:2821-2827.

82. Tan SL, Wood AM: Chronic obstructive pulmonary disease and co-morbidities: a review and consideration of pathophysiology. Panminerva Med 2009, 51:81-93.

83. Wilk JB, Walter RE, Laramie JM, Gottlieb DJ, O'Connor GT: Framingham Heart Study genome-wide association: results for pulmonary function measures. BMC Med Genet 2007, 8(Suppl 1):S8

84. Vozarova B, Fernandez-Real JM, Knowler WC, Gallart L, Hanson RL, Gruber JD, Ricart W, Vendrell J, Richart C Tataranni PA, Wolford JK: The interleukin-6 (-174) G/C promoter polymorphism is associated with type-2 diabetes mellitus in Native Americans and Caucasians. Hum Genet 2003, 112:409-413.

85. Yasmin, McEniery CM, O'Shaughnessy KM, Harnett P, Arshad A, Wallace S, Maki-Petaja K, McDonnell B, Ashby MJ, Brown J, Cockcroft JR, Wilkinson IB: Variation in the human matrix metalloproteinase-9 gene is associated with arterial stiffness in healthy individuals. Arterioscler Thromb Vasc Biol 2006, 26:1799-1805.

86. Hersh CP, Demeo DL, Lange C, Litonjua AA, Reilly JJ, Kwiatkowski D, Laird N, Sylvia JS, Sparrow D, Speizer FE, Weiss ST, Silverman EK: Attempted replication of reported chronic obstructive pulmonary disease candidate gene associations. Am J Respir Cell Mol Biol 2005, 33:71-78.

87. Hersh CP, Demeo DL, Lazarus R, Celedon JC, Raby BA, Benditt JO, Criner G, Make B, Martinez FJ, Scanlon PD, Sciurba FC, Utz JP, Reilly JJ, Silverman EK: Genetic association analysis of functional impairment in chronic obstructive pulmonary disease. Am J Respir Crit Care Med 2006, 173:977-984.

88. Smith CA, Harrison DJ: Association between polymorphism in gene for microsomal epoxide hydrolase and susceptibility to emphysema. Lancet 1997, 350:630-633.

89. Yoshikawa M, Hiyama K, Ishioka S, Maeda H, Maeda A, Yamakido M: Microsomal epoxide hydrolase genotypes and chronic obstructive pulmonary disease in Japanese. Int $J$ Mol Med 2000, 5:49-53.

90. Sandford AJ, Chagani T, Weir TD, Connett JE, Anthonisen NR, Pare PD: Susceptibility genes for rapid decline of lung function in the lung health study. Am J Respir Crit Care Med 2001, 163:469-473

91. Ishii T, Keicho N, Teramoto S, Azuma A, Kudoh S, Fukuchi $Y$, Ouchi $Y$, Matsuse T: Association of Gc-globulin variation 
with susceptibility to COPD and diffuse panbronchiolitis. Eur Respir J 2001, 18:753-757.

92. Horne SL, Cockcroft DW, Dosman JA: Possible protective effect against chronic obstructive airways disease by the GC2 allele. Hum Hered 1990, 40:173-176.

93. Schellenberg D, Pare PD, Weir TD, Spinelli JJ, Walker BA, Sandford AJ: Vitamin D binding protein variants and the risk of COPD. Am J Respir Crit Care Med 1998, 157:957-961.

94. Harrison DJ, Cantlay AM, Rae F, Lamb D, Smith CA: Frequency of glutathione S-transferase M1 deletion in smokers with emphysema and lung cancer. Hum Exp Toxicol 1997, 16:356-360.

95. He JQ, Connett JE, Anthonisen NR, Pare PD, Sandford AJ: Glutathione S-transferase variants and their interaction with smoking on lung function. Am J Respir Crit Care Med 2004, 170:388-394.

96. Baranova H, Perriot J, Albuisson E, Ivaschenko T, Baranov VS, Hemery B, Mouraire P, Riol N, Malet P: Peculiarities of the GSTM1 0/0 genotype in French heavy smokers with various types of chronic bronchitis. Hum Genet 1997, 99: 822-826.

97. He JQ, Ruan J, Connett JE, Anthonisen NR, Pare PD, Sandford AJ: Antioxidant gene polymorphisms and susceptibility to a rapid decline in lung function in smokers. $A m \mathrm{~J}$ Respir Crit Care Med 2002, 166:323-328.

98. Gilliland FD, Gauderman WJ, Vora H, Rappaport E, Dubeau L: Effects of glutathione-S-transferase M1, T1, and P1 on childhood lung function growth. Am J Respir Crit Care Med 2002, 166:710-716.

99. Ishii $T$, Matsuse $T$, Teramoto $S$, Matsui $H$, Miyao M, Hosoi $T$, Takahashi H, Fukuchi Y, Ouchi Y: Glutathione S-transferase P1 (GSTP1) polymorphism in patients with chronic obstructive pulmonary disease. Thorax 1999, 54:693-696.

100. Guenegou A, Leynaert B, Benessiano J, Pin I, Demoly P, Neukirch F, Boczkowski J, Aubier M: Association of lung function decline with the heme oxygenase-1 gene promoter microsatellite polymorphism in a general population sample. Results from the European Community Respiratory Health Survey (ECRHS), France. J Med Genet 2006, 43:e43.

101. Yamada N, Yamaya M, Okinaga S, Nakayama K, Sekizawa K, Shibahara S, Sasaki H: Microsatellite polymorphism in the heme oxygenase-1 gene promoter is associated with susceptibility to emphysema. Am J Hum Genet 2000, 66:187195.

102. Minematsu $N$, Nakamura $H$, Tateno $H$, Nakajima T, Yamaguchi $\mathrm{K}$ : Genetic polymorphism in matrix metalloproteinase-9 and pulmonary emphysema. Biochem Biophys Res Commun 2001, 289:116-119.

103. Zhou M, Huang SG, Wan HY, Li B, Deng WW, Li M: Genetic polymorphism in matrix metalloproteinase-9 and the susceptibility to chronic obstructive pulmonary disease in Han population of south China. Chin Med J (Engl) 2004, 117:1481-1484

104. Poller W, Faber JP, Weidinger S, Tief K, Scholz S, Fischer M, Olek K, Kirchgesser M, Heidtmann HH: A leucine-to-proline substitution causes a defective alpha 1-antichymotrypsin allele associated with familial obstructive lung disease. Genomics 1993, 17:740-743

105. Poller W, Faber JP, Scholz S, Weidinger S, Bartholome K, Olek K, Eriksson S: Mis-sense mutation of alpha 1-antichymotrypsin gene associated with chronic lung disease. Lancet 1992, 339:1538.

106. Foreman MG, Demeo DL, Hersh CP, Carey VJ, Fan VS, Reilly JJ, Shapiro SD, Silverman EK: Polymorphic variation in surfactant protein $B$ is associated with COPD exacerbations. Eur Respir J 2008, 32:938-944.

107. Celedon JC, Lange C, Raby BA, Litonjua AA, Palmer LJ, DeMeo DL, Reilly JJ, Kwiatkowski DJ, Chapman HA, Laird N, Sylvia JS, Hernandez M, Speizer FE, Weiss ST, Silverman EK: The transforming growth factor-beta1 (TGFB1) gene is associated with chronic obstructive pulmonary disease (COPD). Hum Mol Genet 2004, 13:1649-1656.

108. Sakao S, Tatsumi K, Igari H, Shino Y, Shirasawa H, Kuriyama $\mathrm{T}$ : Association of tumor necrosis factor alpha gene promoter polymorphism with the presence of chronic obstructive pulmonary disease. Am J Respir Crit Care Med 2001, 163:420-422.

109. Sakao S, Tatsumi K, Igari H, Watanabe R, Shino $Y$, Shirasawa $\mathrm{H}$, Kuriyama $\mathrm{T}$ : Association of tumor necrosis factor-alpha gene promoter polymorphism with low attenuation areas on high-resolution CT in patients with COPD. Chest 2002, 122:416-420.

110. Huang SL, Su CH, Chang SC: Tumor necrosis factor-alpha gene polymorphism in chronic bronchitis. Am J Respir Crit Care Med 1997, 156:1436-1439.

111. Gompertz S, Stockley RA: A randomized, placebo-controlled trial of a leukotriene synthesis inhibitor in patients with COPD. Chest 2002, 122:289-294.

112. Mahler DA, Huang S, Tabrizi M, Bell GM: Efficacy and safety of a monoclonal antibody recognizing interleukin-8 in COPD: a pilot study. Chest 2004, 126:926-934.

113. Decramer M, Rutten-van Molken M, Dekhuiizen PN, Troosters T, van Herwaarden C, Pellegrino R, van Schayck CP, Olivieri D, Del Donno M, De Backer W, Lankhorst I, Ardia A: Effects of $\mathrm{N}$-acetylcysteine on outcomes in chronic obstructive pulmonary disease (Bronchitis Randomized on NAC CostUtility Study, BRONCUS): a randomised placebo-controlled trial. Lancet 2005, 365:1552-1560.

114. Bruce C, Thomas PS: The effect of marimastat, a metalloprotease inhibitor, on allergen-induced asthmatic hyperreactivity. Toxicol Appl Pharmacol 2005, 205:126-132.

115. Mao JT, Goldin JG, Dermand J, Ibrahim G, Brown MS, Emerick A, McNitt-Gray MF, Gjertson DW, Estrada F, Tashkin DP, Roth MD: A pilot study of all-trans-retinoic acid for the treatment of human emphysema. Am J Respir Crit Care Med 2002, 165:718-723.

116. Celik P, Sakar A, Havlucu Y, Yuksel H, Turkdogan P, Yorgancioglu A: Short-term effects of montelukast in stable patients with moderate to severe COPD. Respir Med 2005, 99:444-450.

117. Rubinstein I, Kumar B, Schriever C: Long-term montelukast therapy in moderate to severe COPD--a preliminary observation. Respir Med 2004, 98:134-138.

Published: 30 November 2009

doi:10.1186/gm112

(c) 2009 BioMed Central Ltd 